\title{
SUSTAINABLE MANAGEMENT OF NATURAL RESOURCES AND EXTENSION STRATEGIES: AN APPLICATION OF ANP
}

\author{
Mousa Kazemi* \\ Agriculture Faculty \\ Islamic Azad University \\ Varamin, Tehran, Iran \\ Email: mousa_kazemi@yahoo.com \\ Iraj Malek Mohammadi \\ Department of Agricultural Extension and Education \\ Tehran University \\ Karaj, Tehran, Iran \\ Email: irajmalek@yahoo.com \\ Davood Samari \\ Agriculture Faculty \\ Islamic Azad University \\ Garmsar, Tehran, Iran \\ Email: drsamari@yahoo.com
}

\begin{abstract}
The purpose of this paper is to analyze the strategic and control criteria influencing the Sustainable Management of Land and Water Resources (SMLWR). This paper also examines priorities of extensional education strategies, including protection, supporting and networking, with respect to the SMLWR. This study was conducted in the Hable-Rud catchment which is an arid watershed affected by a high number of social and environmental disasters. The study is comprised of a survey using Delphi technique to explore relevant elements to the SMLWR and then analyzing decision networks using ANP techniques. Technical software including SPSSWIN and Super Decisions were used for statistical analysis and paired comparison analysis, respectively. The survey tools were several sequential questionnaires which were used for gathering information from 34 scientists and practitioners connected to the SMLWR in Hable-Rud. This article presents the decision networks under 13 high rank control criteria, for excellence in Extension Education, given out through benefits, opportunities, costs and risks (BOCR) merits. These consist of dependency and feedback between alternatives cluster and decision-makers' clusters in every subnet under control criterion. Two formulas including additive and multiplicative expressions were used for synthesizing the final model, and they both confirmed that the networking strategy is the best one with respect to the SMLWR. Sensitivity analysis shows that the priorities are responsible in increasing the cost or risk values but they are stable when the benefits and opportunities values change.
\end{abstract}

Keywords: ANP, BOCR model, catchment management, extension strategy, sustainable development

\section{Introduction}

Optimized use of scarce natural resources is a major challenge in Iran. Although Iranian traditional farming and pasture systems are always sustainable, inappropriate technologies destroying conventional lifestyle and native governance institutions have often caused harmful social and economic consequences like poverty, social gaps, mass migration, food, fresh water and shelter

\footnotetext{
${ }^{*}$ Corresponding author
} 
shortages; or environmental impacts like decreasing fertility capacity of lands, biodiversity endangerment, desertification, drought and flood. The primary questions here are: who is responsible for the current malpractices and who has to fix them. Indeed, it is a complex issue which involves a range of individuals, communities and local and national authorities. These issues address sustainable development that is going to be a cardinal concern around the world in the near future.

According to the General Assembly of the United Nations in 1987, sustainable development implies meeting the needs of the present without compromising the ability of future generations to meet their own needs (UN, 1987). It addresses, for example, use of an area within its capacity to maintain its cultural or natural values, ensuring that our use does not reduce the capability to meet the needs and desires of next generations. Considering the United Nations Conference on Environment and Development in Rio de Janeiro in 1992, sustainable development has become a significant and vital point in every international and national decision.

As a result of this conference and its declaration, Agenda 21, countries are required to incorporate environmental considerations in economic and social decision making and policy analysis by creating proper institutional structures. Integrated planning and management of land resources is a particular subject of Agenda 21 that is managed by the Food and Agriculture Organisation of the United Nations (FAO). Islamic Republic of Iran is a leader in incorporating this momentous declaration in practice resulting in the Hable-Rud programme. This programme that is called "Sustainable Management of Land and Water Resources" (SMLWR) which is a pilot programme that covers several chapters of Agenda 21 and is jointly directed by collaboration of FAO and the United Nations Development Programme (UNDP) since 1997. This article presents some results derived from a broad research (Kazemi, 2007) that was conducted by authors on the Hable-Rud catchment.

Hable-Rud watershed is a pilot project dedicated to searching and finding an integrated social, economic and environmental programming system. Physically, it is a 1.2 million ha area including 280 small villages in Semnan and Tehran provinces which are located in vicinity of Tehran, the capital city with a population of over 12 million and other large cities like Semnan, Damavand, Firozkoh and Garmsar with millions of people living in them. People who want to migrate to Tehran temporarily settle in such places both in rural and urban settings.

This article provides an application of the AHP/ANP techniques to study sustainable management of natural resources in course of Hable-Rud catchment in Iran. It starts with a brief review of the main features of the research subject and importance of MCDM methodology to deal with that. Afterwards, the main model and the strategic and criteria containing clusters and elements are reviewed, followed by an analysis of the alternatives and a discussion about the results arising from paired comparison matrices. Finally, a conclusion section summarizes the final outcomes.

\subsection{Sustainable Management of Natural Resources Approach}

Feeny and Clarket (2008) argue that there is a significant correlation between environmental crises and social and economic challenges. In most places this involves resisting poverty, infectious and prevalent diseases, and warmth, shelter and food shortages as well as inequality, anarchy, genocide and war. These countries often have no reasonable priority for spending their scarce sources to combat environmental disasters. Otherwise, as Bauer (2008) has discussed, the environment is a general and overall factor which affects other social, economic and even security issues in local, regional and global scales. In this point, for instance, a development programme aimed to reduce the poverty or food security should be considered through a supplementary environmental assessment project.

Brierley and Fryirs $(2008,5)$ criticize the current development programmes for focusing on "mismatches of scale, which is the mindset associated with discipline-bound practices, and steps that can be taken to move beyond such thinking". They mention that the programme should socially, 
economically and environmentally merge whole dimensions of the sustainable development, which could practically represent protection, enrichment and improvement of ecosystem resources, by means of an integrated catchment management. They suggest an alternative solution that strives to reconcile "command and control perspectives", which focuses on engineering river systems for human purposes, with "ecosystem perspectives", which pursue a balance between human needs and environmental values. They have also emphasized that this paradigm should shift within a biophysically possible, economically reasonable and socially acceptable solution. Of course, such a pragmatic solution requires methodological review and specific and adjusted methods and techniques in practice. According to this ecosystem-based approach, allocation of scarce resources to river management projects requires articulated decision-making systems which are able to identify and analyse both scholarly and practical data in a unique model which could prioritise the interventions at a specific ecological site like a catchment basin.

Ghoddosi (2004) explains that the "catchment management" terminology has been applied since 1896 as a natural unit for the management and preparation of land aimed to maximize the productivity of resources with the minimum biologically destructive consequences. It is a systematic way to design, propose and apply the various human activities like land usage, agro-forestry, dam building, road building, harvesting, cropping, establishing protected reserves based on scarcity of possessions into the catchment basin. Chronologically, the latest terms like "Integrated Management of Natural Resources, "Integrated Watershed Management" and recently "Sustainable Management of Land and Water Resources (SMLWR)" have been used instead of or to complement the catchment management. Sharifi and Norozi (2003) show that SMLWR approach attempts a coordinated and well-behaved management of economic, social, biological and physical systems with the least negative effects on the resources, while also secures and supplies for the benefits of the community, whereas they are essential to exercise governmental authority so as to regulate and define land use in such a way to observe the overall capacity of the catchment, to control water quality and quantity, and to minimize soil erosion and sediment deposition. According to the Hable-Rude programme official document (SMLWR, 2007) SMLWR is a catchment management oriented programme with particular emphasis on suitable institutional arrangements or comprehensive management systems towards food security and poverty reduction by sustainable governance of natural resources.

The focal point of this national programme was a collective decision making mechanism targeting food security and natural resources conservation by participation of Local Communities (LCs). First phase of the plan was started in 1997 and after reviewing of its documents, events, evaluation research findings and funding the plan; second phase finally was begun in 2007. The main aim of the SMLWR plan is to improve proper methods, strategies, policies, and tools for overcoming: (1) continuing degradation of land and water resources, (2) limited community participation in decision making, (3) a lack of holistic and integrated approaches to development programming, (4) institutional and human resources weaknesses and (5) unsustainable planning and management of the resources (UNDP, 2007). Practically, achieving these goals requires a bottom-up approach with special mechanisms to empower LCs to participate. It means local people should be able to find out and analyse the problematic situations and decide about their priorities, suggest suitable solutions, have confidence to allocate and invest their own money and gain outsider support for carrying out the projects and finally monitor and evaluate the progress of the plan.

\subsection{Criteria/Alternatives for Extension Education}

Extension Education is basically defined as an on-going process of giving useful information and techniques to people and then motivating those people to obtain the required knowledge, attitudes, skills, and aspirations to utilize this information or technology effectively. It appears within different structures like a private, non-profit or governmental organisation. The extension methods vary from training facilitators or local leaders, field and face-to-face contact, in person or phone-based consultation, TV and radio programmes or even loading informative webpage. Archer et al. (2007) represent the criteria for excellence in cooperative extension in the US which are almost similar to 
countries like Iran. Extension education is recognized as an integral part of the university or research centre's outreach effort, its actions are employed to seek and use stakeholder input that results in relevant educational programmes. Client satisfaction and creating best practices and exemplary programme are also two important criteria. The performance of extension programme is usually evaluated by its capability to make economic impact and the change in the level of knowledge, attitude, skills, aspiration and behaviour of clients. Amount of funding by sources for extension organisation is the last criterion that is mentioned.

Extension has crucial contribution to sustainable natural resource management based on recognition of native practices and their reinforcement and adjustment with engineering commands. Kazemi and Shahvali (2003) who have studied indigenous knowledge of natural resources in Zohreh catchment, located in Fars province in Iran, confirm that there is a rich source of knowledge and practice of sustainable land and water management. It results in dwellers being capable of accepting responsibility of natural resource governance without any outsiders' management. This research shows that there is no means rather than public participation for the conservation of land and water resources. Public participation will appear only when the local communities posses the selfconfidence for teamwork.

In this article usage of Extension Education System is summarized as three strategies which represent three different approaches in this area. They are introduced in the following:

Protection Strategy: Protection Strategy is the usual and top-down strategy used by governmental Extension Management authorities that rely on transfer of technology and innovations to final users without any assessment of local needs. In this strategy, technologies are outside-made which are introduced to dwellers in catchment basin by governmental officials. Doing the protection, renewal and development activities derived from river engineering commands without participation of local communities are examples of application of this strategy. The main purpose of this strategy is protection, renewal and development of the territory's possessions like farm and range lands, water and biological resources in the catchment.

Supported Strategy: This strategy has its roots in dwellers' requirements assessment; however, stages of extension programme are led by officials. Participation of dwellers is just wanted in the implication stage of projects. It is not necessary that dwellers directly benefit from the projects. Their collaboration is not required in the planning and evaluation stages of the catchment development programming processes. The main purpose of this strategy is the support of people dwelling in the catchment basin as wall protection of the territory's possessions.

Networking Strategy: Networking strategy is a bottom-up or participatory approach. Technology is inside-made either arisen from indigenous knowledge and practices or adjusted techniques with social, economic and environmental circumstances considered in catchment basin. The main purpose of this strategy is the empowerment of dwellers in social networking towards sustainable and valuable living as dynamic and active local communities who are responsible for disaster control for territory's possessions like farming and range lands, water and biological resources.

\subsection{AHP/ANP Methodology}

Developing and managing the use of natural resources is a complicated practice which needs taking decisions that unavoidably involve several objectives of an economic, environmental and social nature. A review of the applications of Multiple Criteria Decision Making (MCDM) techniques in natural resource management, provided by Romero and Rehman (1987) shows that this paradigm has technically been very successful to formulate and explain the land and water management issues. Multi-Criteria Decision Making (MCDM) methodology can easily be applied by any decision-maker 
with a low level of mathematic knowledge, for instance governmental officials or a promoter or a native group of local experts, to make a perfect decision.

The Analytic Network Process (ANP) with supporting software "Super Decisions Model", developed by Thomas L. Saaty (2004b), is the mathematical framework enabling us to model systems with feedback and dependence. It is a theory of measurement applied to unravel complex problems, specially, the higher influence among several stakeholders or alternatives with respect to different criteria or attributes, to evaluate the dominance of criteria with respect to a higher criterion. Dominance is a primitive concept used in making comparisons among elements with respect to the possession of an attribute or the fulfilment of conditions as criteria (Saaty, 2004b).

The ANP is a general framework for a detailed analysis of single and collective decisions with economical, social and environmental dimensions. It allows both interaction and feedback within clusters of elements (inner dependence) and between clusters of elements (outer dependence). Such feedback best captures the complex effects of interaction and intervention in human society, especially when risk, complexity, and uncertainty are involved. The ANP networks of influence include all the factors and criteria, tangible and intangible that have bearing on making a best decision. The ANP deals with the Benefits, Opportunities, Costs, and Risks (BOCR) merits. The determination of relative weights in the ANP is based on the pair-wise comparisons. Finally, combined into a whole and comprehensive decision. The analysis is conducted as follows (Saaty, 2003):

Step 1: Developing priorities for personal values,

Step 2: Ratting each of the four BOCR merits on the personal (or collective) values,

Step 3: Creating and prioritizing the control criteria for each of the BOCR,

Step 4: Creating and prioritizing the decision networks for each of these control criteria, and finally, obtaining the answer,

Step 5: Synthesizing the priorities of the alternatives for benefits, opportunities, costs and then for risks, thus obtaining four different rankings for each alternative.

The priorities of BOCR are used to weight and synthesize the overall weights of the alternatives obtained from the four merit structures. There are several formulaic expressions for synthesizing (consist of Multiplicative and Additive) the composite priorities with the use of weights that allow for differences in relative importance of the factors from a personal or collective view.

\section{Materials and Methods}

This study is an applied research that was conducted in two separate stages. The first stage carried out by using a survey method by applying the Delphi technique to find out effective components and elements of decision making and judgment about the SMLWR programme and performance of its associated promotion or Extension Education System in the Hable-Rud catchment basin. It also presents effective macro components and elements which might affect performance of the programme in the catchment. The next stage was using components and elements as cluster of criteria and nodes to design decision networks employing the AHP/ANP methodology.

Initially, 34 scientists and practitioners out of 38, who are affiliated with the Hable-Rud programme from 1997 to 2005, were asked to participate in the first stage of this research aimed at determination and definition of components and their relevant elements. In the second stage, a group of participants that were collaborating with the programme and were known as an effective member in the decision making were questioned.

The research tools in the first stage were three sequential questionnaires. The face and content validity of questionnaires and also consistency of answers were determined by a panel of experts consisting of specialists in watershed management, natural resources and Extensional Education. The first questionnaire was an open-question type which collected their statements about research subjects. 
After content analyses of the collected information, findings were presented in the next questionnaire to measure participants' agreement about every statement and their sorting. Finally, the third questionnaire was designed to ask their final viewpoints and rate the resulted statements. A six point scale from 0 to 5 was used for rating the elements in second and final questionnaires. The final statements and their associated categories are listed in tables 1 and 2. In this stage, the prioritizing process of elements has been conducted by comparing means and standard deviations of each element with another only according to their interval values. Thus the ranking value shows the importance degree of each element, with an assumption of independency of factors. As readers can see, these ranks for the same criteria are completely different from ones that produced in the next stage of research because of calculating priorities with the assumption of dependency among criteria in the second stage.

AHP/ANP methodology that has been improved by Professor Thomas L. Saaty, was applied in the second stage of research. Furthermore, Super Decisions software and its manual, written by Rozann W. Saaty (2003) employed for analysis and design of decision networks. The pair-wise comparison technique with a 9 point scale was used for judgment about dominancy and importance of elements and clusters with respect to a specific goal or control criterion.

To avoid probable errors during the judgments, an inconsistency index with value lower than 0.1 for every set of judgment was considered. It was carried out by reviewing the most inconsistent value in every matrix, using Super Decisions software manual. Sensitivity analysis was also applied for all control criteria and each of BOCR merits.

\section{Main Model}

\subsection{BOCR networks and Cluster Definitions}

Table 1 comprises of elements that introduce the judgment criteria for prioritizing extension strategies with respect of SMLWR programme. These have been classified into the BOCR merits. These criteria were rated using a six point scale from 0 to 5 . The mean scores of statements show that the value of all conceptual statements are between "strong" to "very Strong" importance with respect to SMLWR performance, 3.68 for "Incompatibility of SMLWR with National Societal and Economic Development Programme" under the risks component and 4.62 for "Establishing Responsible Community-Based Organisations and Facilitators for SMLWR programme" under societal opportunity component.

The first to tenth most important judging factors about extension system performance with respect to SMLWR programme are "Responsible CBOs for SMLWR", "Empowerment of LCs to Governance", "Employing HR for Extension", "Extension Research Funds", "Increasing LCs' Revenue", LCs' Attitude About Sustainability", "Officials' Attitude About Sustainability", "LCs Money Spending", "Adopting LCs' Monitoring Roles" and finally "Learning How to Participate", respectively. The statements and components mentioned in the table 1 are examined as BOCR merits of extension system with respect to SMLWR programme in the ANP model in the next stage of research.

\subsection{Strategic Criteria Definitions}

Table 2 presents all categorized and agreed components which are overall criteria affecting SMLWR programme performances in Hable-Rud watershed. They are known as strategic criteria in AHP/ANP methodology. 
Table 1. BOCR of Extension Education System with respect to SMLWR programme

\begin{tabular}{|c|c|c|c|c|c|c|c|c|c|c|c|c|}
\hline \multirow{2}{*}{\multicolumn{2}{|c|}{ Component }} & \multirow{3}{*}{$\begin{array}{l}\text { Conceptual Statements (control Criteria) } \\
\begin{array}{l}\text { Determination of Environmental protection and } \\
\text { development measures }\end{array}\end{array}$} & \multirow{3}{*}{$\begin{array}{l}\mathbf{F} \\
34\end{array}$} & \multicolumn{6}{|c|}{ Valid Percentage of Responds } & \multirow{3}{*}{$\begin{array}{l}\text { Mean } \\
3.91\end{array}$} & \multirow{3}{*}{$\begin{array}{r}\text { SD } \\
0.793\end{array}$} & \multirow{3}{*}{ 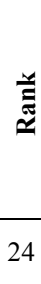 } \\
\hline & & & & \multirow{2}{*}{ 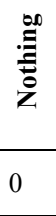 } & \multirow{2}{*}{ 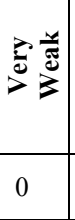 } & \multirow{2}{*}{2.9} & \multirow{2}{*}{ 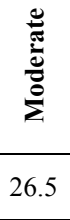 } & \multirow{2}{*}{ 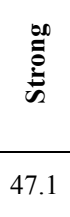 } & \multirow{2}{*}{ } & & & \\
\hline \multirow{11}{*}{$\begin{array}{l}\stackrel{0}{0} \\
\text { 离 } \\
\text { ص }\end{array}$} & $\stackrel{0}{\Xi}$ & & & & & & & & & & & \\
\hline & 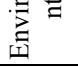 & $\begin{array}{l}\text { Increasing Environmental Sustainability } \\
\text { Responsibility }\end{array}$ & 34 & 0 & 0 & 0 & 17.6 & 41.2 & 41.2 & 4.24 & 0.741 & 11 \\
\hline & \multirow{7}{*}{$\begin{array}{l}\frac{\pi}{0} \\
\frac{\pi}{8} \\
\mathscr{D}\end{array}$} & $\begin{array}{l}\text { Merging divided Administrations' Purposes into } \\
\text { SMLWR programme }\end{array}$ & 34 & 0 & 0 & 2.9 & 14.7 & 50 & 32.4 & 4.12 & 0.769 & 19 \\
\hline & & $\begin{array}{l}\text { Sustainable Settlement of dwellers in Watershed } \\
\text { by encouraging people to participate in SMLWR } \\
\text { beneficiaries }\end{array}$ & 34 & 0 & 0 & 0 & 20.6 & 38.2 & 41.2 & 4.21 & 0.770 & 14 \\
\hline & & $\begin{array}{l}\text { Change in governmental officials' attitude } \\
\text { towards Sustainability }\end{array}$ & 34 & 0 & 0 & 0 & 17.6 & 26.5 & 55.9 & 4.38 & 0.779 & 7 \\
\hline & & $\begin{array}{l}\text { Change in Local Communities attitude towards } \\
\text { Sustainability }\end{array}$ & 34 & 0 & 0 & 0 & 20.6 & 17.6 & 61.8 & 4.41 & 0.821 & 6 \\
\hline & & $\begin{array}{l}\text { Learning how to participate by Local } \\
\text { Communities }\end{array}$ & 34 & 0 & 0 & 2.9 & 26.5 & 14.7 & 55.9 & 4.24 & 0.955 & 10 \\
\hline & & $\begin{array}{l}\text { Empowerment of Local Communities to } \\
\text { governance of Watershed Resources }\end{array}$ & 34 & 0 & 0 & 0 & 8.8 & 23.5 & 67.6 & 4.59 & 0.657 & 2 \\
\hline & & $\begin{array}{l}\text { Promotion of Social Trust/Confidence among } \\
\text { dwellers in the watershed }\end{array}$ & 34 & 0 & 0 & 0 & 17.6 & 41.2 & 41.2 & 4.24 & 0.741 & 13 \\
\hline & \multirow{2}{*}{$\stackrel{0}{0} .0$} & Increasing Local Communities' revenue & 34 & 0 & 0 & 0 & 11.8 & 35.3 & 52.9 & 4.41 & 0.701 & 5 \\
\hline & & $\begin{array}{l}\text { Increasing Local Communities share and Money } \\
\text { spending in SMLWR }\end{array}$ & 34 & 0 & 0 & 0 & 8.8 & 47.1 & 44.1 & 4.35 & 0.646 & 8 \\
\hline \multirow{5}{*}{ 点 } & \multicolumn{2}{|c|}{$\begin{array}{l}\text { Of Employing Efficacious Human Resources for } \\
\text { Extension sector }\end{array}$} & 31 & 0 & 0 & 0 & 9.7 & 32.3 & 58.1 & 4.48 & 0.677 & 3 \\
\hline & \multicolumn{2}{|c|}{$\begin{array}{l}\text { Increasing costs of preparing and equipping to cover } \\
\text { Extension Services }\end{array}$} & 34 & 0 & 0 & 0 & 23.5 & 41.2 & 35.3 & 4.12 & 0.769 & 18 \\
\hline & \multicolumn{2}{|c|}{$\begin{array}{l}\text { Capacity Building/On-Governmental Reformation Cost } \\
\text { aimed at replacing Collective Governance }\end{array}$} & 34 & 0 & 0 & 0 & 47.1 & 29.4 & 23.5 & 3.76 & 0.819 & 26 \\
\hline & \multicolumn{2}{|c|}{$\begin{array}{l}\text { Increasing Social-Economic and Extension-Educational } \\
\text { Research Fund }\end{array}$} & 34 & 0 & 0 & 0 & 17.6 & 20.6 & 61.8 & 4.44 & 0.786 & 4 \\
\hline & \multicolumn{2}{|c|}{$\begin{array}{l}\text { Lengthened Projects cost because of changing in } \\
\text { Management Paradigm to Participatory }\end{array}$} & 31 & 6.5 & 3.2 & 6.5 & 16.1 & 35.5 & 32.3 & 3.68 & 1.423 & 29 \\
\hline \multirow{8}{*}{ 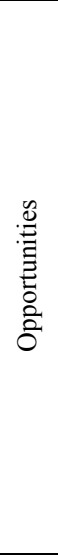 } & \multirow{3}{*}{$\begin{array}{l}\frac{\pi}{0} \\
\frac{\pi}{0} \\
0 \\
\mathscr{n}\end{array}$} & $\begin{array}{l}\text { Training Responsible Governmental Officials for } \\
\text { SMLWR programme }\end{array}$ & 34 & 0 & 0 & 5.9 & 26.5 & 23.5 & 44.1 & 4.06 & 0.983 & 20 \\
\hline & & $\begin{array}{l}\text { Establishing Responsible Community-Based } \\
\text { Organisations and Facilitators for SMLWR } \\
\text { programme }\end{array}$ & 34 & 0 & 0 & 0 & 0 & 38.2 & 61.8 & 4.62 & 0.493 & 1 \\
\hline & & $\begin{array}{l}\text { Reformation in National Extensional Education } \\
\text { System regarding to SMLWR programme }\end{array}$ & 34 & 0 & 0 & 5.9 & 8.8 & 44.1 & 41.2 & 4.21 & 0.845 & 15 \\
\hline & \multirow{2}{*}{ 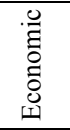 } & $\begin{array}{l}\text { Reducing Deprivation and Poverty of dwellers in } \\
\text { the watershed }\end{array}$ & 34 & 0 & 0 & 0 & 17.6 & 41.2 & 41.2 & 4.24 & 0.741 & 12 \\
\hline & & Efficacious measures in cropping and Land Using & 34 & 0 & 0 & 5.9 & 5.9 & 52.9 & 35.3 & 4.18 & 0.797 & 16 \\
\hline & \multirow{3}{*}{ 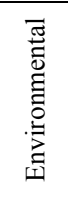 } & $\begin{array}{l}\text { Exercising of national Environmental Rights, } \\
\text { Authorities and Security }\end{array}$ & 34 & 0 & 0 & 8.8 & 29.4 & 38.2 & 23.5 & 3.76 & 0.923 & 27 \\
\hline & & $\begin{array}{l}\text { Promising to sustainability legislated by } \\
\text { Community-Based Organisations }\end{array}$ & 34 & 0 & 0 & 8.8 & 23.5 & 50 & 17.6 & 3.76 & 0.855 & 28 \\
\hline & & $\begin{array}{l}\text { Adopting Local Communities' Monitoring Roles } \\
\text { in watershed management }\end{array}$ & 34 & 0 & 0 & 0 & 8.8 & 52.9 & 38.2 & 4.29 & 0.629 & 9 \\
\hline \multirow{6}{*}{$\frac{n}{\tilde{n}}$} & $\begin{array}{l}\text { Gover } \\
\text { progra }\end{array}$ & $\begin{array}{l}\text { mental Indifference with respect to SMLWR } \\
\text { mme Performance }\end{array}$ & 34 & 0 & 0 & 11.8 & 11.8 & 44.1 & 32.4 & 3.97 & 0.969 & 22 \\
\hline & $\begin{array}{l}\text { Dilute } \\
\text { Resea }\end{array}$ & $\begin{array}{l}\text { Connections between (Gap) Extension and } \\
\text { h Sectors to address SMWLR }\end{array}$ & 34 & 0 & 0 & 8.8 & 8.8 & 41.2 & 41.2 & 4.15 & 0.925 & 17 \\
\hline & $\begin{array}{l}\text { Incom } \\
\text { Natior } \\
\text { Progra }\end{array}$ & $\begin{array}{l}\text { atibility of SMLWR/Extension Sub-system with } \\
\text { al Societal and Economic Development } \\
\text { mme }\end{array}$ & 34 & 0 & 8.8 & 0 & 29.4 & 38.2 & 23.5 & 3.68 & 1.121 & 30 \\
\hline & $\begin{array}{l}\text { Oppos } \\
\text { Unpor }\end{array}$ & $\begin{array}{l}\text { tion with SMLWR by dwellers in watershed and } \\
\text { ularity }\end{array}$ & 34 & 0 & 8.8 & 2.9 & 17.6 & 35.3 & 35.3 & 3.85 & 1.209 & 25 \\
\hline & $\begin{array}{l}\text { Abusi } \\
\text { Practi }\end{array}$ & $\begin{array}{l}\text { g and avoiding to use Indigenous Knowledge and } \\
\text { es in the SMLWR programme }\end{array}$ & 34 & 0 & 0 & 5.9 & 32.4 & 26.5 & 35.3 & 3.91 & 0.965 & 23 \\
\hline & $\begin{array}{l}\text { Forbe } \\
\text { Gover }\end{array}$ & $\begin{array}{l}\text { ring to use capacities of Private and Non- } \\
\text { mental Sectors }\end{array}$ & 34 & 0 & 0 & 5.9 & 17.6 & 41.2 & 35.3 & 4.06 & 0.886 & 21 \\
\hline
\end{tabular}


Table 2. Components and factors that affect SMLWR performances in Hable-Rud watershed

\begin{tabular}{|c|c|c|c|c|c|c|c|c|c|c|c|}
\hline \multirow{2}{*}{ 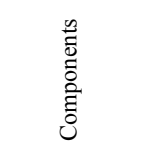 } & \multirow[b]{2}{*}{ Conceptual Statements (Strategic criteria) } & \multirow[b]{2}{*}{$\mathrm{F}$} & \multicolumn{6}{|c|}{ Valid Percentage of responds } & \multirow[b]{2}{*}{ mean } & \multirow[b]{2}{*}{ SD } & \multirow[b]{2}{*}{ 荎 } \\
\hline & & & $\begin{array}{l}\stackrel{0}{\Xi} \\
\text { : } \\
\text { Z }\end{array}$ & $\frac{3}{5} \frac{3}{5}$ & 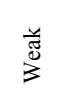 & $\begin{array}{l}\frac{\pi}{\pi} \\
\frac{\vec{d}}{0} \\
\sum\end{array}$ & 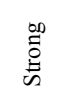 & 疍总 & & & \\
\hline \multirow{4}{*}{ 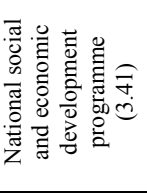 } & Stabilised management in land and water resources sector (1MPS) & 34 & 5.9 & 8.8 & 2.9 & 23.5 & 38.2 & 20.6 & 3.41 & 1.417 & 34 \\
\hline & $\begin{array}{l}\text { Coordinated planning authorities in local, province and national } \\
\text { levels (2MPS) }\end{array}$ & 34 & 0 & 0 & 0 & 8.8 & 50 & 41.2 & 4.32 & 0.638 & 9 \\
\hline & Priority of natural resource in macro-planning system (3MPS) & 34 & 0 & 0 & 0 & 14.7 & 47.1 & 38.2 & 4.24 & 0.699 & 12 \\
\hline & Supported by Knowledge-based planning approach (4MPS) & 34 & 0 & 0 & 0 & 26.5 & 55.9 & 17.6 & 3.91 & 0.668 & 22 \\
\hline \multirow{6}{*}{ 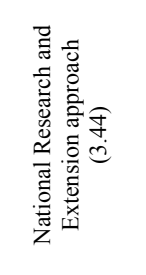 } & Stabilisation of extension scheme in SMLWR programme (1ES) & 34 & 0 & 8.8 & 0 & 32.4 & 32.4 & 26.6 & 3.68 & 1.147 & 30 \\
\hline & Existing of active professional institutions of Extension (2ES) & 34 & 0 & 0 & 0 & 20.6 & 70.6 & 8.8 & 3.88 & 0.537 & 23 \\
\hline & Firm linkages among Extension and Research sectors (3ES) & 34 & 0 & 0 & 0 & 11.8 & 73.5 & 14.7 & 4.03 & 0.521 & 19 \\
\hline & Level of bureaucracy in Extension contacts (4ES) & 30 & 0 & 0 & 3.3 & 16.7 & 40 & 40 & 4.17 & 0.834 & 15 \\
\hline & Improve professional affiliations of Extension activists (5ES) & 33 & 0 & 0 & 6.1 & 18.2 & 57.6 & 18.2 & 3.88 & 0.781 & 24 \\
\hline & Availability of practical Extension services (6ES) & 34 & 0 & 0 & 8.8 & 41.2 & 47.1 & 2.9 & 3.44 & 0.705 & 32 \\
\hline \multirow{3}{*}{ 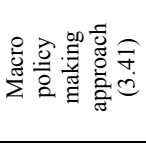 } & The power and privilege of LCs in national policies (1MPM) & 34 & 0 & 0 & 2.9 & 14.7 & 50 & 32.4 & 4.12 & 0.769 & 16 \\
\hline & Stable dealing with promotion of sustainability in society (2MPM) & 34 & 5.9 & 2.9 & 20.6 & 20.6 & 14.7 & 35.3 & 3.41 & 1.520 & 33 \\
\hline & $\begin{array}{l}\text { Compilation and ratification of supportive acts and regulations for } \\
\text { SMLWR approach (3MPM) }\end{array}$ & 34 & 0 & 0 & 2.9 & 14.7 & 44.1 & 38.2 & 4.18 & 0.797 & 14 \\
\hline \multirow{6}{*}{ 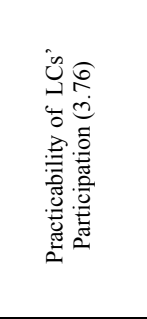 } & Equitable allocation of national resources to local projects (1PLC) & 34 & 0 & 0 & 0 & 5.9 & 70.6 & 23.5 & 4.18 & 0.521 & 13 \\
\hline & $\begin{array}{l}\text { Cooperative acquisition by LCs to be able to collaborate with } \\
\text { SMLWR programme (2PLC) }\end{array}$ & 34 & 0 & 0 & 0 & 17.6 & 23.5 & 58.8 & 4.41 & 0.783 & 5 \\
\hline & $\begin{array}{l}\text { Collective decision body to cope with Complexity of socio-political } \\
\text { structures in dwelled watershed (3PLC) }\end{array}$ & 34 & 0 & 0 & 0 & 38.2 & 44.1 & 17.6 & 3.79 & 0.729 & 26 \\
\hline & $\begin{array}{l}\text { Previous participation of LCs in prior rural development programme } \\
(4 \mathrm{PLC})\end{array}$ & 34 & 0 & 0 & 0 & 47.1 & 29.4 & 23.5 & 3.76 & 0.819 & 27 \\
\hline & Cooperative abilities of LCs in development programme (5PLC) & 34 & 0 & 0 & 0 & 11.8 & 29.4 & 58.8 & 4.47 & 0.706 & 3 \\
\hline & $\begin{array}{l}\text { LCs' responsibility for sustainable natural resources management } \\
\text { (6PLC) }\end{array}$ & 34 & 0 & 0 & 0 & 8.8 & 55.9 & 35.3 & 4.26 & 0.618 & 11 \\
\hline \multirow{5}{*}{ 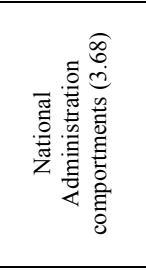 } & $\begin{array}{l}\text { Eliminate promotion of politicization between organisational bodies } \\
\text { which leading SMLWR programme ( } 1 \mathrm{AS} \text { ) }\end{array}$ & 34 & 5.9 & 8.8 & 0 & 26.5 & 11.8 & 47.1 & 3.71 & 1.567 & 28 \\
\hline & Organizational compatibility among Govt authorities (2AS) & 32 & 0 & 9.4 & 0 & 9.4 & 50 & 31.3 & 3.94 & 1.134 & 21 \\
\hline & $\begin{array}{l}\begin{array}{l}\text { Eliminate parallel and overlapping duties by divided Govt } \\
\text { departments (3AS) }\end{array} \\
\end{array}$ & 34 & 0 & 0 & 8.8 & 20.6 & 32.4 & 38.2 & 4.00 & 0.985 & 20 \\
\hline & Govt committees for coordinating SMLWR programme (4AS) & 34 & 0 & 0 & 2.9 & 23.5 & 38.2 & 35.3 & 4.06 & 0.851 & 18 \\
\hline & $\begin{array}{l}\text { Reinforcing of NGOs' situation in national administration system } \\
\text { (5AS) }\end{array}$ & 34 & 0 & 0 & 2.9 & 41.2 & 41.2 & 14.7 & 3.68 & 0.768 & 29 \\
\hline \multirow{3}{*}{ 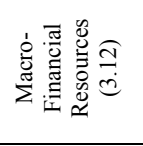 } & Decentralized allocation of credits to cover SMLWR (1MFR) & 34 & 0 & 5.9 & 8.8 & 29.4 & 41.2 & 14.7 & 3.50 & 1.052 & 31 \\
\hline & Assurance of investment return for every spending (2MFR) & 34 & 0 & 0 & 8.8 & 50 & 41.2 & 0 & 3.32 & 0.638 & 35 \\
\hline & $\begin{array}{l}\text { Effective and fair allocation of credits to Extension activities } \\
\text { (3MFR) }\end{array}$ & 34 & 0 & 5.9 & 8.8 & 61.8 & 14.7 & 8.8 & 3.12 & 0.913 & 36 \\
\hline \multirow{3}{*}{ 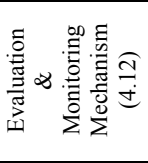 } & $\begin{array}{l}\text { Documentary of SMLWR projects to find out strength, weaknesses, } \\
\text { opportunities and threats points (1EM) }\end{array}$ & 34 & 0 & 0 & 2.9 & 0 & 50 & 47.1 & 4.41 & 0.657 & 4 \\
\hline & Assess performance of SMLWR programs frequently (2EM) & 34 & 0 & 0 & 8.8 & 14.7 & 32.4 & 44.1 & 4.12 & 0.977 & 17 \\
\hline & $\begin{array}{l}\text { Pilot SMLWR programme before implementing in widespread } \\
(3 \mathrm{EM})\end{array}$ & 34 & 0 & 0 & 2.9 & 11.8 & 35.3 & 50 & 4.32 & 0.806 & 10 \\
\hline \multirow{3}{*}{ 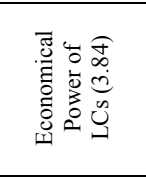 } & $\begin{array}{l}\text { Livelihood securing programme for dwellers into catchment } \\
\text { (1EPLC) }\end{array}$ & 34 & 0 & 0 & 0 & 5.9 & 52.9 & 41.2 & 4.35 & 0.597 & 8 \\
\hline & $\begin{array}{l}\text { Remedy frangibility of substantial production and exploitation of } \\
\text { agro-ecosystem (2EPLC) }\end{array}$ & 32 & 0 & 0 & 6.3 & 28.1 & 40.6 & 25 & 3.84 & 0.884 & 25 \\
\hline & $\begin{array}{l}\text { Improve financial and economical facilities for using by LCs to } \\
\text { spend in SMLWR projects (3EPLC) }\end{array}$ & 34 & 0 & 0 & 0 & 5.9 & 50 & 44.1 & 4.38 & 0.604 & 6 \\
\hline \multirow{3}{*}{ 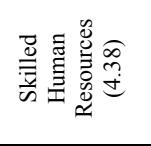 } & Recruitment well-educated scientists and skilled officials (1EES) & 34 & 0 & 0 & 0 & 14.7 & 20.6 & 64.7 & 4.50 & 0.749 & 2 \\
\hline & $\begin{array}{l}\begin{array}{l}\text { Responsible officials to guarantee LCs' interests in SMLWR } \\
\text { programme (2EES) }\end{array} \\
\end{array}$ & 34 & 0 & 0 & 0 & 8.8 & 44.1 & 47.1 & 4.38 & 0.652 & 7 \\
\hline & Desirable managers to lead SMLWR programme by LCs (3EES) & 34 & 0 & 0 & 0 & 2.9 & 41.2 & 55.9 & 4.53 & 0.563 & 1 \\
\hline
\end{tabular}

F: Frequency of respondents

LCs: Local Communities

Govt: Government or Governmental

The mean scores of statements mention that all statements are in range of moderate and more importance with respect to SMLWR performance, with 3.12 for "Effective and fair allocation of credits to Extension activities" under the Macro-Financial Resources component and 4.53 for 
"Desirable managers to lead SMLWR programme by LCs" under Skilled Human Resources component. There is a rank column made by comparing means and standard deviations (SD) of each statement. According to this ranking method, the first to fifth highest ranking statements include "Desirable managers to lead SMLWR programme by LCs", "Recruitment of well-educated scientists and skilled officials", "Cooperative abilities of LCs in development programme", "Documentation of SMLWR projects to find out strength, weaknesses, opportunities and threats points" and "Cooperative acquisition by LCs to be able to collaborate with SMLWR programme". The statements and components mentioned in the table 2 are considered as overall and high-potency criteria over SMLWR programme for rating of BOCR merits in the next stage of research.

\subsection{Control Criteria and Subnets of the BOCR}

The components in Table 1 are considered as the BOCR merits and each of them has relative control criteria whose priorities are developed through pair-wise comparison. Table 4 shows the calculated priorities of each control criteria derived from the Unweighted Supermatrix. The thirteen highest priorities control criteria are selected to create the associated network sub-models that contain the alternatives of the decision and clusters of each group of decision-makers with respect to SMLWR programme. The alternatives cluster appears exactly the same way under every subnet of each control criterion and its priorities are determined in each of the subnets. As Saaty $(2008,297)$ mentions "these are weighted by their control criterion, and these results are multiplied in the BOCR weights from the rating model and combined to give the final results". There are three promotion strategies being considered for the SMLWR programme in Hable-Rud catchment. The alternatives are defined in the following.

\subsection{Alternatives (in every subnet)}

○ Protection Strategy

- Supported Strategy

- Networking Strategy

In the following, the decision networks, including associated clusters and nodes, under each control criterion are shown:

\subsection{Clusters and Nodes in the Benefits/ Economic Subnet}

3.5.1 Money Spending by LCs network: financial investment of local communities in the SMLWR projects.

- Alternatives

- Governmental Sectors: Governmental Sectors consist of Local Government, Technical and Executive Management, Extension Management and Social Workers

- Local Government: Local Government in the village or watershed for example "Dehyary", "Bakhshdary" and "Farmundary".

- Executive Administrations: Local branch or representative of technical organisations in watershed such as the Cooperative Home

- Extension Management: Centre that presents consulting services to farmers and rangers

- Local Experts: Local people with high indigenous knowledge and technical abilities (Powers) about living, agriculture, forestry, rangeland management

- Women: Superior or different-maker women in Local Community

- Superior Persons: Successful and pattern farmers or rangers in Local Community

- Local Leaders: Elder and indigenous persons that others follow them in living

- Community-Based Organizations: Local organizations with high influence in communities that make solidarity and empathy into people for development

- Islamic Councils: Islamic councils in local communities such as rural, sectors, towns

- Creative Clubs: Creative clubs and building centres or people organizations in Local Communities for watershed management and development 
- Traditional Cooperatives: Traditional and local cooperatives in Local Communities in watershed

\subsection{Clusters and Nodes in the Benefits/ Social Subnet}

3.6.1 LCs Governance Empowerment network: Empowering Local Communities by means of establishing cooperative decision making institutions

- Alternatives

- Governmental Sectors

- Executive Administrations

- Extension Management

- Local Experts

- Women

- Superior Persons

- Local Leaders

- Community-Based Organizations

- Islamic Councils

- Creative Clubs

3.6.2 Learning how to participate in a network: Training Local Communities aimed at teaching people how to participate in the SMLWR programme

- Alternatives

- Governmental Sectors

- Executive Administrations

- Extension Management

- Non-Governmental Sectors: Non-Governmental Sectors consist of NGOs, International Sponsors/Supporters Organizations and Mass Media

- NGOs: Domestic or National level NGOs in the areas of environment protection, rural development, sustainable development, social security and human welfare

- International Support Organisations: International Supportive Organization that could relate to UN Organization or Programmes or International NGOs

- Mass Media: Mass media such as radio, TV, newsletters and internet and so on

3.6.3 Sustainability Attitude- Officials Network: Growing belief in sustainable and integrated management of natural resources among governmental staff

- Alternatives

- Governmental Sectors

- Local Government

- Executive Administrations

- Extension Management

- Non-Governmental Sectors

- NGOs

- International Support Organisations

3.6.4 Sustainable Settlement network: Encouragement of Local Community to participate in administration of watershed basin and permanent dwelling

- Alternatives

- Governmental Sectors

- Executive Administration

- Extension Management

- Local Experts

- Women

- Superior Persons 
- Scientific and Educational Sectors: Scientific, Research and Educational Sectors as Schools, Colleges, Faculty or Research Organisations or Vocational Education Centres

○ Teachers: Teachers that live in Local Community and assist the development of watershed

- Spiritual Leader: Leader/Imam of Mass Prayers that live in Local Community and assist the development of watershed

\subsection{Nodes in the Costs Subnet Clusters}

3.7.1 Capacity Building Cost Network: funding capacity building of SMLWR programme or ongovernmental reformation costs to replace collective and participatory governance

- Alternatives

- Governmental Sectors

- Local Government

- Executive Administrations

- Extension Management

- Non-Governmental Sectors

- NGOs

- International Support Organisations

3.7.2 Extension Research Funds Network: Increasing in social-economic and extensional education research funds

- Alternatives

- Governmental Sectors

- Executive Administrations

- Extension Management

- Non-Governmental Sectors

- NGOs

- International Support Organisations

- Community-Based Organizations

- Islamic Councils

- Local Development Funds: Local development and micro-financial funds like Sandogh-e-Gharzolhasane

\subsection{Clusters and Nodes in the Opportunities/ Economic Subnet}

3.8.1 Reducing Poverty Network: Reducing of privation and poverty of dwelling local communities at the catchment basin

- Alternatives

- Governmental Sectors

- Local Government

- Executive Administrations

- Extension Management

- Non-Governmental Sectors

- NGOs

- International Support Organisations

- Mass Media: Mass media: radio, TV, newsletters and internet

- Local Experts

- Women

- Superior Persons

- Local Leader

○ Community-Based Organizations

- Islamic Councils

- Local Cooperatives 
- Creative Clubs

- Local Development Funds

- Scientific and Educational Sectors

- Teachers

- Spiritual Leaders

- Research Sector: Research Sectors consist of researchers and research managers that are active at Local Community

- Students: Graduates or undergraduates living with families in local Community

\subsection{Clusters and Nodes in the Opportunities/ Social Subnet}

3.9.1 Responsible CBOs for SMLWR network: Establishing responsible community based organisations and facilitators for SMLWR programme

- Alternatives

- Governmental Sectors

- Local Government

- Executive Administrations

- Extension Management

- Community-Based Organizations
- Islamic Councils
- Local Cooperatives
- Creative Clubs

\subsection{Nodes in the Risks Subnet Clusters}

3.10.1 Abusing Indigenous Knowledge network: Abusing and avoiding to use indigenous knowledge and practices in the SMLWR programme

- Alternatives

- Governmental Sectors

- Executive Administrations

- Extension Management

- Local Experts

- Women

- Superior Persons

- Local Leader

- Community-Based Organizations

- Local Cooperatives

- Scientific and Educational Sectors

- Research Sector

3.10.2 Forbearing Private and NGOs Network: Forbearing and not using capacities of NGO and Private Sector in Watershed Management

- Alternatives

- Governmental Sectors

- Local Government

- Executive Administrations

- Extension Management

- Non-Governmental Sectors

- NGOs

- International Support Organisations

- Local Experts

- Women

- Superior Persons

- Local Leader 
- Community-Based Organizations

- Islamic Councils

- Local Cooperatives

3.10.3 Incompatibility of SMLWR Network: Incompatibility of the SMLWR with national societal and economic development programme, as a five year integrated programme in Iran

- Alternatives

- Governmental Sectors

- Local Government

- Executive Administrations

- Extension Management

- Non-Governmental Sectors

- NGOs

- Community-Based Organizations

- Islamic Councils

- Creative Clubs

3.10.4 Opposition with SMLWR network: Opposition with the SMLWR programme by dwellers in watershed and unpopularity because of un-honoured promises

- Alternatives

- Governmental Sectors

- Local Government

- Executive Administrations

- Extension Management

- Local Experts

- Women

- Local Leader

○ Community-Based Organizations

- Islamic Councils

- Local Cooperatives

\subsection{Decision Model for Rating Strategic Criteria}

Table 3 presents the priorities of each strategic criterion and its relevant sub-criteria which are rated by means of pair-wise comparisons. It is an Analytic Hierarchical Processing (AHP) model including nine high-potency criteria with their associated sub-criteria derived from Table 2, macro/overall factors that affect performance and the priority of the SMLWR programme in Hable-Rud catchment.

According to this table "Practicability of LCs Participation" is by far the most effective criteria on SMLWR programme, with 36.5 percent of global priorities. This is more than twice the priority of any other high potency criteria. There are six sub-criteria under this umbrella criterion, with ranks bellow 15th out of 30. The highest ranking sub-criteria belongs to "Cooperative abilities of LCs in Development Programme", which represents 13.5 percent of the global priorities. Furthermore, "LCs' responsibility for sustainable natural resources management" and "cooperative acquisition by LCs to be able to collaborate with SMLWR programme" have stood in ranking 4 and 6 respectively.

"Macro financial resources system" has the second highest priority, with 15.1 percent, closely followed by "Macro policy making approach", which is the third most effective high-potency criteria. There are also "Decentralized Allocation of Credits to Cover SMLWR Programme", which has the second rank and "Compilation and Ratification of Supportive Acts and Regulations for SMLWR Approach", which has the third rank out of 30.

Following the list, the three criteria including "Economic power of Local Communities", "National social and economic development programme" and "National Research and Extension approach" have almost similar priorities, with $9.5,8.8$ and 8.4 percent of total priorities respectively. 
SMLWR is a bottom-up planning approach which has been introduced into the existing national planning structure based on a hierarchical and top-down planning system in Iran. This system is known as the National Social-Economic Development Programme. It is composed of four subcriteria, stabilised management in national planning for sustainable environment, coordination among planning authorities (local, provincial and national), priority of SMLWR in national planning system and, knowledge-based supports.

Of the nine overall criteria in the first column of table, the least effective one is "National Administration Comportments", with just about 2 percent of the whole priorities, which is only slightly less than "Evaluation \& Monitoring Mechanism" and "Skilled Human Resources", which are 4.7 and 3 percent of the priorities respectively.

\subsection{Rate Benefits, Opportunities, Costs and Risks}

Table 4 represents the 30 control criteria under the benefits, opportunities, costs and risks and their priorities. The Merits values in the first column and the criteria and sub-criteria values were correspondingly prioritized through pair-wise comparisons and by means of using the Super Decisions Rating Command and the Unweighted Supermatrix. The global priorities values are obtained by multiplying the values of relative merit, criterion and sub-criterion.

According to the table, "reducing poverty", "extension of research funds", "abusing indigenous knowledge" and "empowerment of local communities to govern" are the most effective opportunity, cost, risk and benefit criteria. They include overall priorities of about 37 percent.

According to the table, "empowerment of local communities to governance", "learning how to participate", "local communities money spending", and "sustainable settlement" are the most effective benefit criteria, with overall ranking of 5,8,9 and 12 out of 30 .

In the cost merit cluster, "extension of research funds", "capacity building costs" and "equipping extension services", with respective ranking of 2, 6 and 13, are the most costly dominative criteria.

The economic criterion of "reducing deprivation and poverty of dwellers in the watershed" as the most possible consequence of SMLWR programme is an outstanding prioritized opportunity and the first most effective criteria, which itself represents 13.9 percent of global priorities. Other dominative opportunity criterion is "establishing responsible CBOs for SMLWR programme", with a rank of 7 out of 30 .

The most risky criteria include "abusing indigenous knowledge of sustainable management of land and water resources", "opposition with SMLWR programme", "incompatibility of SMLWR programme with national societal and economic development programme", and "forbearance to use the private and non-governmental sectors", with respective ranking of 3, 4, 10 and 11 .

These are the top thirteen highest priorities criteria, which explain about 76.9 percent of global priorities, were obtained to set up the decision networks. 
Table 3. Rating High-potency Criteria with respect to Sustainable Management of Land and Water Resources (SMLWR) programme

\begin{tabular}{|c|c|c|c|c|}
\hline $\begin{array}{l}\text { High-potency } \\
\text { Criteria }\end{array}$ & Sub-Criteria (Name in Super Decisions software) & $\begin{array}{l}\text { Local } \\
\text { Priorities }\end{array}$ & $\begin{array}{l}\text { Global } \\
\text { Priorities }\end{array}$ & Rank \\
\hline \multirow{4}{*}{$\begin{array}{l}\text { National social } \\
\text { and economic } \\
\text { development } \\
\text { programme } \\
(0.088)\end{array}$} & Stabilised management in land and water resources sector (1MPS) & 0.198 & 0.017 & 17 \\
\hline & $\begin{array}{l}\text { Coordinated planning authorities in local, province and national levels } \\
\text { (2MPS) }\end{array}$ & 0.145 & 0.013 & 21 \\
\hline & Priority of natural resource in macro-planning system (3MPS) & 0.483 & 0.042 & 7 \\
\hline & Supported by knowledge-based planning approach (4MPS) & 0.174 & 0.015 & 19 \\
\hline \multirow{6}{*}{$\begin{array}{l}\text { National } \\
\text { Research and } \\
\text { Extension } \\
\text { approach }(0.084)\end{array}$} & Stabilisation of extension scheme in SMLWR programme (1ES) & 0.193 & 0.016 & 18 \\
\hline & Existing of active professional institutions of Extension (2ES) & 0.124 & 0.010 & 22 \\
\hline & Firm linkages among Extension and tesearch sectors (3ES) & 0.339 & 0.029 & 11 \\
\hline & Level of bureaucracy in Extension contacts (4ES) & 0.178 & 0.015 & 20 \\
\hline & Improve professional affiliations of Extension activists (5ES) & 0.088 & 0.007 & 25 \\
\hline & Availability of practical Extension services (6ES) & 0.079 & 0.007 & 28 \\
\hline \multirow{3}{*}{$\begin{array}{l}\text { Macro policy } \\
\text { making approach } \\
(0.122)\end{array}$} & The power and privilege of LCs in national policies (1MPM) & 0.173 & 0.021 & 12 \\
\hline & Stable dealing with promotion of sustainability in society (2MPM) & 0.055 & 0.007 & 27 \\
\hline & $\begin{array}{l}\text { Compilation and ratification of supportive acts and regulations for SMLWR } \\
\text { approach (3MPM) }\end{array}$ & 0.772 & 0.094 & 3 \\
\hline \multirow{6}{*}{$\begin{array}{l}\text { Practicability } \\
\text { LCs' } \\
\text { Participation } \\
(0.365)\end{array}$} & $\begin{array}{l}\text { Equitable allocation of national resources to local development projects } \\
\text { (1PLC) }\end{array}$ & 0.055 & 0.020 & 14 \\
\hline & $\begin{array}{l}\text { cooperative acquisition by LCs to be able to collaborate with SMLWR } \\
\text { programme ( } 2 \mathrm{PLC} \text { ) }\end{array}$ & 0.166 & 0.061 & 6 \\
\hline & $\begin{array}{l}\text { Collective decision body to cope with complexity of socio-political structures } \\
\text { in dwelled watershed (3PLC) }\end{array}$ & 0.054 & 0.020 & 15 \\
\hline & Previous participation of LCs in prior rural development programme (4PLC) & 0.099 & 0.036 & 9 \\
\hline & Cooperative abilities of LCs in development programme (5PLC) & 0.369 & 0.135 & 1 \\
\hline & LCs' responsibility for sustainable natural resources management (6PLC) & 0.256 & 0.094 & 4 \\
\hline \multirow{5}{*}{$\begin{array}{l}\text { National } \\
\text { Administration } \\
\text { comportments } \\
(0.018)\end{array}$} & $\begin{array}{l}\text { Eliminate promotion of politicization between organisational bodies which } \\
\text { leading SMLWR programme (1AS) }\end{array}$ & 0.029 & 0.001 & 36 \\
\hline & Organizational compatibility among Govt authorities (2AS) & 0.073 & 0.001 & 35 \\
\hline & Eliminate parallel and overlapping duties by divided Govt departments (3AS) & 0.088 & 0.002 & 34 \\
\hline & Govt committees for coordinating SMLWR programme (4AS) & 0.288 & 0.005 & 31 \\
\hline & Reinforcing of NGOs' situation in national administration system (5AS) & 0.522 & 0.009 & 24 \\
\hline \multirow{3}{*}{$\begin{array}{l}\text { Macro- financial } \\
\text { resources }(0.151)\end{array}$} & Decentralized allocation of credits to cover SMLWR programme (1MFR) & 0.715 & 0.108 & 2 \\
\hline & Assurance of investment return for every spending (2MFR) & 0.067 & 0.010 & 23 \\
\hline & Effective and fair allocation of credits to Extension activities (3MFR) & 0.218 & 0.033 & 10 \\
\hline \multirow{3}{*}{$\begin{array}{l}\text { Evaluation } \\
\text { Monitoring } \\
\text { mechanism } \\
(0.047)\end{array}$} & $\begin{array}{l}\begin{array}{l}\text { Documentary of SMLWR projects to find out strength, weaknesses, } \\
\text { opportunities and threats points (1EM) }\end{array} \\
\end{array}$ & 0.149 & 0.007 & 26 \\
\hline & Assess performance of SMLWR programs frequently (2EM) & 0.066 & 0.003 & 32 \\
\hline & Pilot SMLWR programme before implementing in widespread (3EM) & 0.785 & 0.037 & 8 \\
\hline \multirow{3}{*}{$\begin{array}{l}\text { Economic power } \\
\text { of LCs }(0.095)\end{array}$} & Livelihood securing programme for dwellers into the watershed (1EPLC) & 0.742 & 0.070 & 5 \\
\hline & $\begin{array}{l}\text { Remedy frangibility of substantial production and exploitation of agro- } \\
\text { ecosystem (2EPLC) }\end{array}$ & 0.055 & 0.005 & 30 \\
\hline & $\begin{array}{l}\text { Improve financial and economical facilities for using by LCs to spend in } \\
\text { SMLWR projects (3EPLC) }\end{array}$ & 0.203 & 0.019 & 16 \\
\hline \multirow{3}{*}{$\begin{array}{l}\text { Skilled Human } \\
\text { Resources } \\
(0.030)\end{array}$} & Recruitment of well-educated scientists and skilled officials (1EES) & 0.097 & 0.003 & 33 \\
\hline & $\begin{array}{l}\text { Responsible officials to guarantee LCs' interests in SMLWR programme } \\
\text { (2EES) }\end{array}$ & 0.202 & 0.006 & 29 \\
\hline & Desirable managers to lead SMLWR programme by LCs (3EES) & 0.701 & 0.021 & 13 \\
\hline
\end{tabular}

LCs: Local Communities

Govt: Government or Governmental 
Table 4. Priorities of BOCR merits Control Criteria Hierarchy

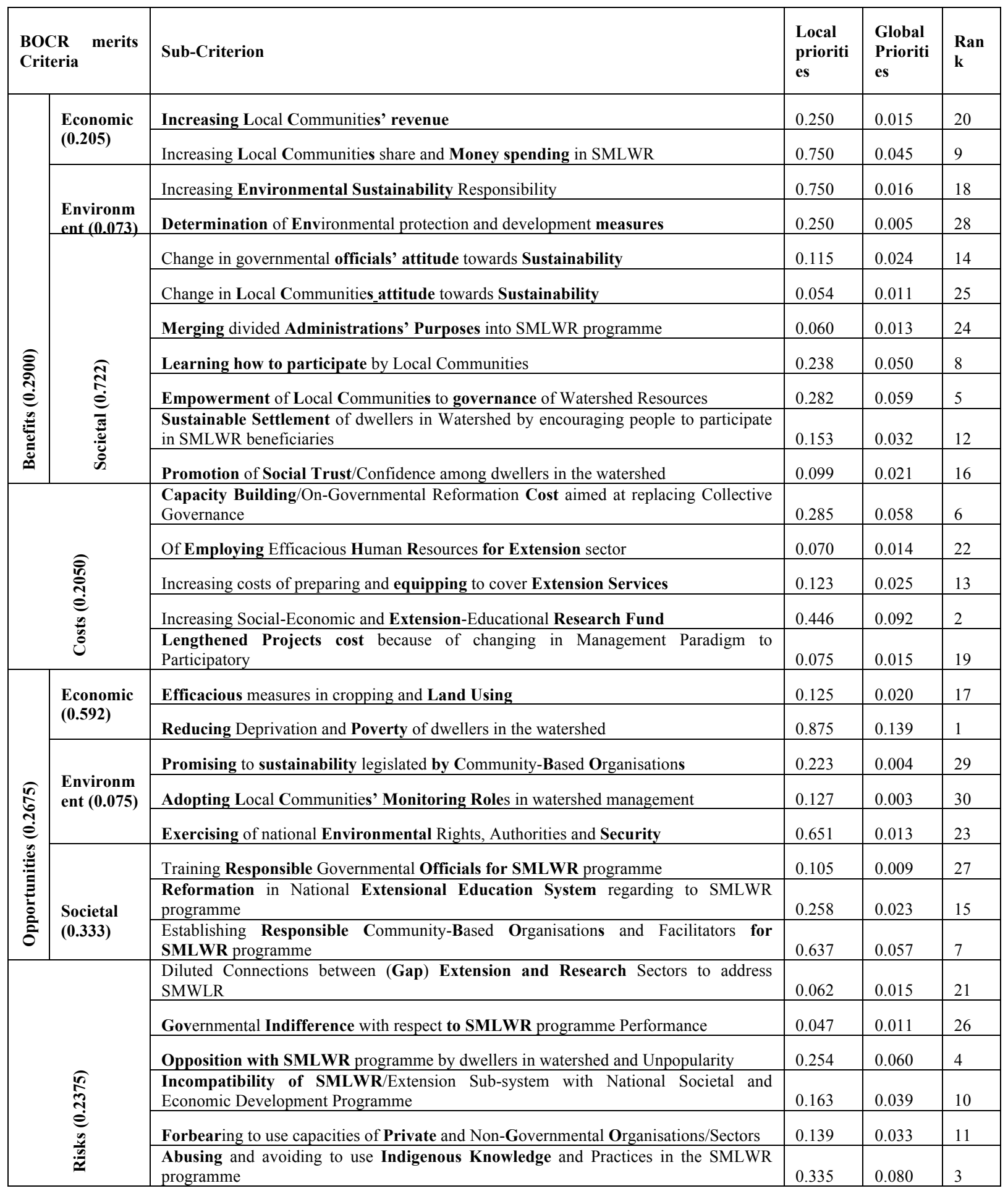

*Bold letters and words show the name of criteria in Super Decisions Software

\subsection{Rate Alternatives and final outcome}

Table 5 shows the final synthesis of the alternatives for each of the BOCR merits and the overall composite normalized priorities calculated by using the additive and the multiplicative synthesis formulas. The effect of using both formulas shows that the networking strategy of extension system has got the highest priority to address SMLWR programme in the Hable-Rud watershed. 
Table 5. Final (Overall) composite priorities using two synthesis expressions and BOCR weights

\begin{tabular}{|l|l|l|l|l|l|l|}
\hline $\begin{array}{c}\text { Extension strategy } \\
\text { for Sustainable } \\
\text { development }\end{array}$ & $\begin{array}{l}\text { Benefits } \\
(0.288)\end{array}$ & $\begin{array}{l}\text { Opportunities } \\
(0.267)\end{array}$ & $\begin{array}{l}\text { Costs } \\
\mathbf{( 0 . 2 0 7 )}\end{array}$ & $\begin{array}{l}\text { Risks } \\
\mathbf{( 0 . 2 3 8})\end{array}$ & $\begin{array}{l}\text { Final } \\
\text { Outcome } \\
\text { Additive }\end{array}$ & $\begin{array}{l}\text { Final } \\
\text { Outcome } \\
\text { Multiplicative }\end{array}$ \\
\hline Networking St. (NS) & 0.6050 & 0.5769 & 0.4150 & 0.4386 & $\mathbf{0 . 4 2 4 5}$ & $\mathbf{0 . 6 5 3 0}$ \\
\hline Protection St. (PS) & 0.1419 & 0.1806 & 0.2909 & 0.2549 & 0.2747 & 0.1176 \\
\hline Supporting St. (SS) & 0.2530 & 0.2425 & 0.2941 & 0.3065 & 0.3008 & 0.2294 \\
\hline
\end{tabular}

\subsection{Sensitivity analysis}

According to the ANP methodology, the sensitivity analysis can only examine by using the additive formula, which includes the rating of BOCR merits. The analysis shows the networking strategy, with normalized priorities of 0.425 , is not sensitive to change of benefits and opportunities values. However, it will not dominate when the value of costs increases by 0.505 and more, so the priority of networking strategy will be changed from first to second to third and the priority of supportive strategy will be the first. Therefore, in the costly circumstances the best alternative would be the supportive strategy.

It is also sensitive to change in the value of risks merit. If the value of risk merit increases by 0.424 and more, the priority of networking strategy will change from first to second to third and the best alternative will be the protection strategy. Therefore in the risky conditions, the best alternative would be the protection strategy.

The examination of sub-criteria shows the final outcome is very stable and does not change the overall ranks except for changes of the one risky criterion, "Incompatibility of SMLWR Programme with the National Societal and Economic Development Programme" where its value changes by 0.668. In this case, the priority of supporting strategy will change from second to third.

\section{Conclusion}

Rating the BOCR control criteria determined thirteen significant criteria for excellence in Extension Education System response to sustainable management of land and water resource in Hable-Rud catchment. Decision networks were designed under all these criteria

As findings represent, compared to Supportive and Protection strategies, Networking is the most successful strategy at encouraging local communities to invest in the river management projects derived from SMLWR programme and generating economic benefits for local people. It is also the more effective strategy to empower local communities for catchment-based natural resources governance, training people on how participate, promotion of sustainability thought in society and government and at last making social benefits for participants, as decision makers, and SMLWR programme, in general.

Using the Networking strategy could result in establishing and developing responsible CommunityBased Organisations (CBOs) and reducing poverty and severe shortages like shelter, food and fresh water. Moreover, the supported and protection strategies are more costly than the networking for the capacity building of participation approach into the government bodies.

Comparing the Supported, Protection and the Networking, the last one is the most effective strategy to control risky criteria with respect to SMLWR programme in the Hable-Rud catchment. Networking is able to employ the indigenous knowledge and practices, encourage the private and non-governmental sectors to engage with SMLWR programme as long as it dilutes criticism and opposes points against that, instead of other strategies. 
According to our findings, Networking is more risky than Supportive and Protective strategies to be reconciled with the National Social and Economic Development Programme.

The findings also show that the Networking strategy for sustainability promotion in the Hable-Rud catchment is determined as the best Extension Education System compared to the Supported and the Protection ones. This strategy strives to empower all stakeholders of the catchment management to make social networking, valuable life and to be sensitive and responsible about any disasters happening in the territory. As the article shows, this strategy relies on establishing and developing collective decision networks by collaboration of relevant groups and individuals with respect to the control criteria. Furthermore, decision makers in Hable-Rud catchment should properly be selected with respect to the associated control criteria.

Finally, according to the sensitivity analysis, on the condition that cost and risk criteria remain stable, the Networking is the most effective strategy of extension system to address sustainable management of land and water resources in the Hable-Rud watershed. However, doubling cost and risk values could alter the priorities of extension strategies. In the highest cost and the highest risk conditions the most dominant strategy would change to supportive and protection ones, respectively. Furthermore, if the SMLWR programme is not compatible with National Social and Economic Development Programme, the supportive strategy would be more suitable than the Protection strategy.

\section{REFERENCES}

Archer, T.M., Warner, P.D., Miller, W., Clark, C.D., James, S. \& Cummings, S.R. (2007). Excellence in extension: two products for definition and measurement. Journal of Extension, 45(1) 1TOT1. http://www.joe.org/joe/2007february/tt1.php.

Asgharpour, M.J. (2004). Multiple decision making, Tehran: the University of Tehran Publications.

Bauer, A. (2008). The environments of poverty; a geographical approach to poverty reduction in Asia and the Pacific. A summary of a book sponsored by the Asian Development Bank (ADB). Retrieved august 2, 2008, from http://www.povertyenvironment.net.

Brierley, G. J., \& Fryirs, K. A. (2008). The Emerging process of river repair. In G. J. Brierley, \& Fryirs, K. A. (Eds.), River futures: an integrative scientific approach to river repair (pp. 1-18). Washington, DC: Island Press.

Feeny, S., \& Clarket, M. (2008). Achieving the millennium development goals in the Asia-Pacefic region: the role of international assistance [Electronic version]. Asia Pacefic Viewpoint, 49(2), 198212.

Forests, Ranges and Watershed Management Organisation of Iran (2005). The national vision of natural resources development for 1400. Planning and Budget and Statistics Office publications.

Kazemi, M. (2007). Designing Collective Decision Networks towards the promotion of Sustainable Development in Hable-Rud Watershed, Semnan, Iran. PhD thesis, The Islamic Azad University, Tehran, Iran.

Kazemi, M. \& Shahvali, M. (2003). A theoretical and empirical model for soil conservation: using indigenous knowledge. African Journal of Indigenous Knowledge Systems. 2(1), 25-36.

Romero, C., \& Rehman, T. (1987). Natural resource management and the use of multiple criteria decision making techniques: a review. Euro. R. agr. Eco., 14, 61-89. 
Saaty, T.L. (2008). Relative measurement and its generalization in decision making. Rev. R. Acad. Cien. Serie A. Mat, 102 (2), 251-318.

Saaty, T.L. (2004a). Decision making, the analytic hierarchy and network processes (AHP/ANP). Journal of Systems Science and Systems Engineering, 13(1), 1-34.

Saaty, T.L. (2004b). The analytic network process: decision making with dependence and feedback. Pittsburgh, PA: RWS Publications.

Saaty R.W. (2003). Decision making in complex environment: Manual of SUPER DECISIONS Software. Pittsburgh, PA: Creative Decisions Foundation Publications.

Sharifi, F. \& Norozi, G.R. (2003). integrated watershed management approach, For.Range Q., 56, 2930 .

United Nations (2009). Commission on sustainable development, agenda 21, http://www.un.org/esa/ dsd/csd/csd index.shtml. Retrieved: 2009-04-02.

United Nations Development Programme (UNDP), (2007). Sustainable management of land and water resources in Hable-Rud basin phase II. www.undp.org.ir/projectdocs/Land $20 \%$ and $20 \%$ water $20 \%$ project $20 \%$ PD.pdf.

United Nations. (1987). Report of the World Commission on Environment and Development. General Assembly Resolution 42/187, 11 December 1987. Retrieved: 2007-04-12. 